\title{
Cost Benefit Analysis (CBA) Program Pemberian Makanan Tambahan (PMT) Susu Pada Karyawan di PT. Trisula Textile Industries Tbk Cimahi Tahun 2018
}

\section{Cost Benefit Analysis Supplementary Feeding Program Of Milk On Employees In PT. Trisula Textile Industries Tbk Cimahi, 2018}

\author{
Ayu Laili Rahmiyati', Asep Dian Abdillah', Susilowati', Dinna Anggaraini \\ ${ }^{1}$ Stikes Jenderal Achmad Yani Cimahi Bandung \\ Korespondensi: Ayu Laili Rahmiyati \\ e-mail: ayunasihin@gmail.com
}

\begin{abstract}
Abstrak
Cost Benefit Analysis (CBA) digunakan untuk proses identifikasi, pengukuran dan perbandingan sosial manfaat dan biaya proyek atau program investasi dalam mengevaluasi penggunaan sumber daya ekonomi yang langka agar dapat digunakan secara efisien. Penelitian ini bertujuan untuk mengetahui perhitungan manfaat dan biaya dari program Pemberian Makanan Tambahan (PMT) susu di PT. Trisula Textile Industries Tbk Tahun 2018 dan untuk menetukan kelayakan akan keberlangsungan program atau kebijakan dari PMT susu. Penelitian ini menggunakan pendekatan kuantitatif.Pengumpulan data dilakukan melalui wawancara, observasi, dan telaah dokumen. Analisis perhitungan menggunakan Payback Period (PP), Net Present Value (NPV), Internal Rate Of Return (IRR), dan Benefit Cost Rate (BCR). Hasil perhitungan nilai NPV pada program PMT susu adalah Rp. 23.534.448,76,-. Kesimpulannya adalah program PMT susu dapat diterima karena NPV > 0. Hasil perhitungan rasio benefit-cost adalah sebesar 2,50 (hasil rasio $\geq 1$ ), artinya program PMT susu tersebut layak untuk tetap berlangsung. PT. Trisula Textile Industries Tbk diharapkan dapat melanjutkan program PMT susu pada karyawan. Data dasar penelitian dapat dijadikan bahan kajian bagi perusahaan untuk menyusun program kesehatan atau peningkatan kesehatan bagi karyawan melalui PMT atau program lain yang lebih prioritas.

Kata Kunci : Kuantitatif, CBA, PMT, NPV, IRR, BCR.
\end{abstract}

\begin{abstract}
Cost Benefit Analysis (CBA) for the process of identification, measurement,comparison social benefits and cost project or investment program to evaluate utilization of scarce economic resources so that it can be used efficiently. This research purposes are calculateing benefits and cost in rupiah from the milk supplementary feeding program (PMT) at PT. Trisula Textile Industries Tbk Year 2018 and deciding feasibility of program or policy sustainability from PMT milk. The research is using quantitative approach. Data collection is done through interviews, observations, and study documents. Calculation is using Payback Period (PP), Net Present Value (NPV), Internal Rate Of Return (IRR), and Benefit Cost Rate (BCR). The result showscalculation of NPV value on milk PMT program obtained results end Rp. 23,534,448,76, - To conclude, the milk PMT program is acceptable because NPV >0. Benefit-cost ratio, is 2.50 ( $\geq 1)$, meaning the milk PMT program is feasible. PT. Trisula Textile Industries Tbk is expected to continue the program of milk PMT. Basic research data could be used for preparing health program or health enhancement for employees through PMT or the other priority programs.

Keywords: Quantitatif, CBA, PMT, NPV, IRR, BCR.
\end{abstract}

\section{Pendahuluan}

Pembangunan bidang kesehatan merupakan bagian yang tidak dapat dipisahkan dari pembangunan nasional ataupun pembangunan daerah. Kesehatan merupakan hak asasi dan investasi serta tanggung jawab bersama, oleh karena itu perlu perhatian khusus dan kerjasama semua pihak atau lintas sektor guna mewujudkan derajat kesehatan yang optimal dari masyarakat (Sitorus, 2017). Berdasarkan Undangundang ketenagakerjaan no 15 tahun 2003 Pasal 86 ayat (1) UU Ketenagakerjaan 2003 menyebutkan bahwa pekerja mempunyai hak untuk memperoleh perlindungan atas kesehatan kerja, yang diwujudkan dengan diselenggarakannya upaya keselamatan dan kesehatan kerja oleh perusahaan (Pasal 86 ayat (2) UU Ketenagakerjaan). Berdasarkan peraturan tersebut, maka perusahaan yang terpapar kimia untuk mencegah dan mengendalikan timbulnya penyakit akibat kerja baik physik maupun psychis, peracunan, infeksi dan penularan (Pasal 3 ayat (1) huruf h UU Keselamatan Kerja) salah satunya dengan cara memberikan tambahan susu bagi pegawai, dengan menganggarkan biaya yang perlu dikeluarkan untuk program makanan tambahan tersebut (PMT). Biaya PMT tersebut perlu dianalisis 
berapa biaya yang dikeluarkan dan manfaat yang diperoleh. Pemberian Makanan Tambahan (PMT) adalah upaya memberikan tambahan makanan dan untuk menambah asupan gizi untuk mencukupi kebutuhan gizi agar tercapainya status gizi yang baik (Kemenkes, 2017)

Analisis Biaya-Manfaat (CBA) adalah proses menggunakan teori, data, dan model untuk menguji produk, pengorbanan, dan kegiatan untuk menilai tujuan yang relevan dan solusi alternatif (Womer, Bougnol, Dula, \& Retzlaff-Roberts, 2006 dalam Misuraca, 2014). Program kesehatan yang dianggap sebagai program investasi oleh perusahaan kimia yang mempunyai resiko terpapar zat kimia dilakukan dengan cara membuat program peningkatan gizi karyawan dengan memberikan susu setiap hari untuk menetralisir racun pada tubuh akibat paparan zat kimia selama bekerja, hal ini disebabkan dalam susu terdapat antidotum yang bisa menangkap dan mengendapkan racun yang masuk ke dalam tubuh.

Susu memiliki kandungan kalsium dan magnesium yang dapat membantu dalam memperkuat tulang dan tubuh yaitu bermanfaat sebagai penetralisir racun yang ada di dalam tubuh, hal ini disebabkan satu zat bernama antidotum yang sanggup menangkap serta mengendapkan racun-racun yang masuk kedalam tubuh. Antidotum digunakan juga untuk mereka yang terkena overdosis akibat pengaruh obat (Khomsan, 2010). Susu adalah cairan emulsi minyak dan air dengan kandungan 3,5 - 4 \% lemak. Selain lemak susu, fase lemak terdiri dari vitamin larut lemak, fosfolipid, karotenoid dan kolesterol, sedangkan fase cair terdiri dari protein, garam mineral, laktosa, dan vitamin larut air (E.J.Lean, 2013).

Menurut data Badan Pusat Statistik (BPS), jumlah tenaga kerja berdasarkan lapangan pekerjaan utama pada tahun 2016 mencapai 120.647.697 orang, di mana yang bekerja di sektor industri sebanyak 15.975 .086 orang dengan kontribusi terbesar dari Provinsi Jawa Barat sekitar 3.892.044 orang (24,93\%), Jawa Tengah 3.219 .793 orang (20,16\%), dan Jawa Timur 2.948.203 orang (18,46\%) (Kemenperin, 2016). Diperkirakan dari jumlah tenaga kerja tersebut, sebesar 35-50\% pekerja terpajan bahaya fisik, kimia, biologi, dan juga bekerja dalam beban kerja fisik dan ergonomi yang melebihi kapasitasnya, termasuk beban psikologis serta stress. Beberapa penyakit yang ditimbulkan oleh racun dapat menyebabkan penyakit katastropik. Pendidikan tentang menjaga kesehatan sejak dini, melalui makanan sehat dan bergizi seimbang, membangun perilaku hidup sehat seperti istirahat yang cukup dan olah raga yang teratur, menghindari kebiasaan buruk merokok dan minum minuman beralkohol penting untuk mengendalikan penyakit katastropik dalam JKN. Dalam jangka panjang investasi pencegahan risiko penyakit kronis di usia dini dapat mengurangi pandemi penyakit kronis yang mahal (katastropik). Penyakit yang pada tingkat rumah tangga tergolong katastropik adalah gagal ginjal, kardiovaskular, kanker, thalassemia dan hemophilia. (Heniwati \& Thabrani, 2016).

Beberapa perusahaan yang memacu dampak negatif terhadap karyawan dan lingkungan antara lain perusahaan yang bergerak dibidang kimia, tekstil, obat dan lain-lain. Salah satu contoh perusahaan yang bergerak di sektor industri antara lain PT. Trisula Textile Industries Tbk merupakan perusahaan yang berstatus Penanam Modal Dalam Negeri (PMDM), bergerak di bidang industri tekstil terpadu. Mengingat PT.Trisula Textile Industries Tbk memproduksi benang tekstur sintesis, polyester fancy suiting, kain celup dan trade mark yang menggunakan bahan/ zat kimia seperti soda api $(\mathrm{NaOH})$, asam klorida $(\mathrm{HCl})$, sodium nitrit $\left(\mathrm{NaNO}_{2}\right)$ dan lain-lain. Banyaknya zat kimia dalam produksi di perusahaan, maka para karyawan mendapat alat pelindung diri, program PMT dan harus patuh pada peraturan kesehatan kerja, untuk meningkatkan kesehatan. Salah satu hasil paling sulit yang ingin dicapai oleh intervensi kesehatan adalah perubahan perilaku Raushan, et all, 2014). Perubahan prilaku untuk mentaati kesehatan dan keselamatan kerja.

Berdasarkan hasil studi pendahuluan sebanyak 280 pekerja $(42,42 \%)$ dari jumlah seluruh karyawan 660 di PT.Trisula Textile Industries Tbk yang berada di beberapa departemen seperti DF (Dying Finishing), yaitu bertugas sebagai timbang obat, dengan waktu terpapar 7 jam nonstop (diselingi waktu istirahat) dengan shift $3 x$, sehingga pada tahun 2003 perusahaan dengan sadar membuat program untuk meminimalisir dampak zat kimia kedalam program perbaikan gizi karyawan pada pekerja dengan memberikan suplement susu sehat setiap hari kepada pekerja yang di rekomendasikan task force gizi, lembaga kerjasama bipartit tentang pemberian nutrisi makanan dan minuman karyawan oleh bagian HCGA, serikat pekerja dan pekerja itu sendiri, yaitu di kenal dengan istilah Pemberian Makanan Tambahan (PMT) susu pada karyawan. 
Dengan adanya program Pemberian Makanan Tambahan (PMT) ini perusahaan harus mengeluarkan biaya bagi investasi program tersebut. Namun seiring berjalannya program PMT susu di PT.Trisula Textile Industries Tbk ini, perusahaan belum pernah melakukan analisis biaya investasi untuk program kesehatan di perusahaan. Oleh karena itu, penelitian ini bertujuan untuk melakukan analisis perhitungan investasi dengan menggunakan rumus diantaranya Payback Period, NPV, IRR, dan $B C R$ yang bermanfaat dalam mengetahui kelayakan program dan pengambilan keputusan perusahaan.

\section{Metodologi Penelitian}

Cost benefit analysis pada penelitian ini adalah analisis yang membandingkan antara biaya (cost) dari suatu program PMT susu dengan output atau keuntungan (benefit) dari program kesehatan. Pada penelitian ini, cost mencerminkan biaya dari investasi program PMT, sedangkan keuntungan mencerminkan hasil dari sebuah program kesehatan PMT. Benefit yang dimaksud disini dapat bersifat netral, positif atau negatif yang bergantung dari hasil yang dicapai. Apabila diterapkan pada sebuah program kesehatan yang dapat meminimalisir zat racun pada pekerja, maka akan menghasilkan benefit yang positif. Sedangkan program kesehatan yang tidak manjur berarti tidak menghasilkan keuntungan (netral) atau bahkan dapat merugikan (benefit yang negatif).

Dalam cost benefit analysis, input (biaya) dan output (hasil program) dikuantifikasi berdasarkan nilai uang. Dengan demikian, akan mudah menentukan apakah hasil dari sebuah program (output) sebanding dengan investasi yang dilakukan. Dari analisis ini dapat diketahui berapa jumlah uang yang pantas/ akan dikeluarkan oleh seseorang untuk mendapatkan suatu keuntungan dalam hal kesehatan.

Dalam penelitian ini, asumsi benefit yang ditimbulkannya yaitu penurunan angka kesakitan, peningkatkan nilai produksi dan produktivitas tenaga kerja. Sedangkan asumsi cost yang ditimbulkannya adalah antara lain: biaya yang harus dikeluarkan untuk membeli produk, beban biaya yang harus ditanggung dalam jangka waktu yang panjang biaya investasi (bahan baku susu), biaya pembelian bahan tambahan (gula), biaya operasional (gaji karyawan, biaya pembelian gas, biaya pembelian plastik, dan biaya pembelian kulkas). Berdasarkan hasil penelitian Marini, Komponen cost dan benefit pada penyelenggaraan laboratorium sederhana bersifat tangible (berwujud uang). Komponen cost terdiri dari biaya investasi biaya fasilitas, biaya operasional dan biaya pemeliharaan fasilitas.

Berdasarkan hasil penelitian Muslim (2015), Cost Benefit analysis pada program kesehatan dalam intervensi ergonomis dan penanganan Low Back Pain (LBP), komponen manfaat-biaya yang dihitung dalam melakukan intervensi ergonomis dalam penanganan LBP adalah biaya perubahan dalam lingkungan fisik dan stasiun kerja, biaya operasional, penghematan biaya perawatan kesehatan pekerja, penghematan biaya turnover dan ketidakhadiran pekerja, dan peningkatan produktivitas.

Kerangka konsep dalam penellitian ini dapat digambarkan dalam diagram berikut :

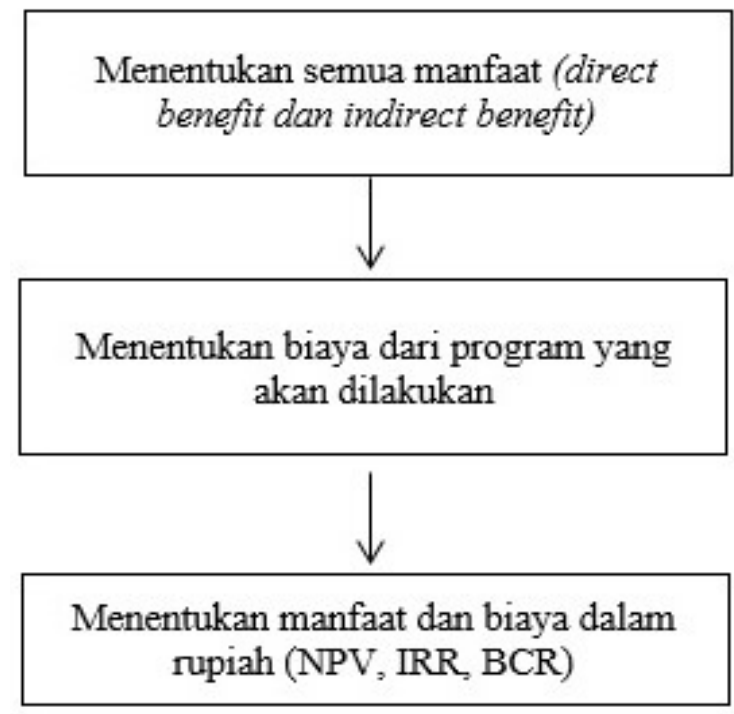

\section{Gambar 1 Kerangka Konsep CBA}

Dalam penelitian ini kerangka konsep yang di kembangkan adalah menganalisis tentang cost benefit analysis program PMT susu di PT. Trisula Textile Industries Tbk Tahun 2018, dimulai dengan identifikasi faktor-faktor yang mempengaruhi perencanaan program PMT susu serta mencari alternatif pemecahan masalah dalam upaya pemutusan kebijakan dalam perencanaan program kesehatan tersebut. Cost benefit analysis digunakan dalam penelitian ini, karena metode ini merupakan salah satu metode analisis kelayakan investasi yang bersandar rasionalitas ekonomi, yang memperhitungkan sisi efisiensi dari program yang telah lama berjalan. Dengan kata lain, suatu pilihan akan dilaksanakan manakala manfaat yang 
ditimbulkan lebih tinggi dari biaya yang dikeluarkan dan sebaliknya berdasarkan tekhnik ini, suatu pilihan akan dihindari manakala manfaat yang dihasilkan tidak sebanding (lebih kecil) dengan biaya yang dikeluarkan.

Jenis penelitian yang digunakan dalam penelitian ini adalah penelitian deskriptif kuantitatif dengan metode survei. Metode deskriptif adalah suatu metode dalam meneliti status sekelompok manusia, suatu objek, suatu set kondisi, suatu sistem pemikiran, ataupun suatu kelas peristiwa pada masa sekarang. Tujuan dari penelitian deskriptif ini adalah untuk membuat deskripsi, gambaran atau lukisan secara sistematis, faktual, dan akurat mengenai fakta-fakta, sifat-sifat serta hubungan antar fenomena yang diselidiki (Nazir, 2005).

\section{Hasil Penelitian}

\section{Identifikasi para pengambil keputusan}

PT. Trisula Textile Industries Tbk berstatus perusahaan penanam modal dalam negeri (PMDN), merupakan perusahaan yang bergerak di bidang industri tekstil terpadu. Mengingat PT Trisula Textile Industries Tbk memproduksi benang tekstur sintesis, polyester fancy suiting, kain celup dan trade mark yang menggunakan bahan / zat kimia seperti soda api $(\mathrm{NaOH})$, asam klorida $(\mathrm{HCl})$, Sodium Nitrit $\left(\mathrm{NaNO}_{2}\right)$ dan lainlain. Maka risiko pekerja terpapar Zat kimia akan tinggi, sehingga perusahaan dengan sadar membuat program untuk meminimalisir dampak zat kimia pada pekerja dengan memberikan susu setiap hari kepada pekerja, hal tersebut dipertegas dengan hasil wawancara dengan Bagian Keuangan/Penganggaran di PT. Trisula Textile Industries Tbk Cimahi. (informan 2).

"setiap tahun ada anggaran untuk pembelian susu kepada karyawan yaitu sebesar Rp. 117.000.000." (informan 2).

Program pemberian makanan tambahan (PMT) susu di PT. Trisula merupakan program perbaikan gizi karyawan yang direkomendasikan Task Force gizi kerja lembaga kerjasama Bipartit tentang pemberian nutrisi makanan dan minuman karyawan oleh bagian HCGA, serikat pekerja dan pekerja itu sendiri yang diselenggarakan mulai tahun 2003. Berikut pernyataan Kepala Kepegawaian HCGA bagian Perencanaan (informan 1).

"Program PMT susu di PT.Trisula Textile Industries

Tbk. berlangsung sudah sejak lama yaitu sejak tahun 2003, dahulu susu yang diberikan dalam bentuk susu siap saji dengan kemasan kotak UHT, yang kemudian berganti menjadi susu kaleng dan berganti kembali menjadi susu murni yang diolah (dipanaskan kembali) secara mandiri di perusahaan”.(informan $1)$.

Karyawan penerima susu di perusaahan ini adalah karyawan yang terpapar zat kimia yaitu sebanyak 280 orang. Tabel 1 menjelaskan pembagian unit kerja dan frekuensi diberikannya susu. Hal tersebut dipertegas dengan hasil wawancara yang dilakukan dengan kepala pengurus program (Informan 3 ).

"Susu diberikan dalam kemasan plastik / gelas yang berisi $250 \mathrm{ml}$. Karyawan yang memperoleh susu diberikan dalam 3 shift yaitu pagi, siang, dan malam. Karyawan yang memperoleh susu dibagi beberapa kelompok menurut tingkat keterpaparan terhadap bahan kimia. Seperti :bagian boiler : diberikan setiap hari, bagian workshop/las : diberikan $3 x$ seminggu, bagian listrik : 1 kali seminggu."(Informan 3)

\section{Menentukan semua manfaat dan biaya dari program yang dilakukan}

Untuk menentukan nilai setiap unsur manfaat (benefit) dan biaya (cost) dari Pemberian Makanan Tambahan (PMT) susu di PT.Trisula Textile Industries Tbk Cimahi dilakukan dengan membandingkan besarnya nilai nominal.

Berdasarkan hasil penelitian program pemberian makanan tambahan (PMT) susu, pada unsur manfaat (benefit) didapat hasil rekapitulasi jumlah penjualan akibat peningkatan nilai produksi yang ditimbulkan dengan adanya program PMT susu adalah Rp. 446,12 miliar meningkat 7,2\% dari sebelumnya Rp.416,16 miliar di tahun 2016. Kemudian dari pengurangan angka kesakitan yaitu tarif pengeluaran BPJS sebesar Rp. 308.432.695,- terhadap seluruh karyawan di PT. Trisula sebanyak 660 pekerja dan produktivitas kerja karyawan dilihat dari karyawan yang lembur dengan diberi tarif Rp.200.000/lembur sebesar Rp. 29.200.000,- sehingga total manfaat yang diperoleh adalah Rp.446.446.543.309,-

\section{Menghitung manfaat dan biaya dalam rupiah}

Biaya merupakan sejumlah uang yang dikeluarkan atas barang atau jasa atau jumlah yang dibutuhkan untuk menciptakan atau memproduksi barang atau jasa tersebut sedangkan harga merupakan sejumlah uang yang diminta, ditawarkan atau dibayarkan untuk suatu barang atau jasa. Dalam menentukan manfaat dan biaya ada tiga metode menganalisa manfaat dan biaya suatu progam/proyek, yaitu NPV 
Tabel 1 Pembagian dan Frekuensi Susu Sehat (Terpapar Bahan Kimia)

\begin{tabular}{|c|c|c|c|c|c|}
\hline \multirow{2}{*}{ Bagian } & \multirow{2}{*}{ seksi } & \multicolumn{3}{|c|}{ Kondisi sekarang } & \multirow{2}{*}{ Ketetapan } \\
\hline & & Waktu terpapar & $\begin{array}{c}\text { Sistem } \\
\text { keria }\end{array}$ & Jumlah susu & \\
\hline DF & $\begin{array}{c}\text { Timbang } \\
\text { obat }\end{array}$ & $\begin{array}{c}7 \text { jam nonstop } \\
\text { (diselingi waktu } \\
\text { istirahat) }\end{array}$ & $\begin{array}{c}3 \text { shift } 3 \\
\text { group }\end{array}$ & $\begin{array}{l}\text { 1x tiap shift } \\
\text { setiap hari }\end{array}$ & - \\
\hline Weaving & Dyeing Test & 2 jam terputus-putus & $\begin{array}{l}3 \text { shift } 4 \\
\text { group }\end{array}$ & $1 x$ tiap shift & - \\
\hline Sizing & Obat & $\begin{array}{c}7 \text { jam nonstop } \\
\text { (diselingi waktu } \\
\text { istirahat) }\end{array}$ & $\begin{array}{c}3 \text { shift } 3 \\
\text { group }\end{array}$ & $\begin{array}{l}\text { 2x tiap shift } \\
\text { (malam) }\end{array}$ & $\begin{array}{l}\text { 1x tiap shift } \\
\text { setiap hari }\end{array}$ \\
\hline Twisting & Dyeing Test & 2 jam terputus-putus & $\begin{array}{l}2 \text { shift } 2 \\
\text { group }\end{array}$ & - & $2 \mathrm{x}$ tiap shift \\
\hline Texturizing & Dyeing Test & 2 jam terputus-putus & $\begin{array}{c}3 \text { shift } 4 \\
\text { group }\end{array}$ & $1 \mathrm{x}$ tiap shift & \\
\hline \multirow[t]{2}{*}{ Utility } & WWT & $\begin{array}{l}7 \text { jam nonstop } \\
\text { (diselingi waktu } \\
\text { istirahat) }\end{array}$ & $\begin{array}{l}3 \text { shift } 3 \\
\text { group }\end{array}$ & $\begin{array}{l}\text { 2x tiap shift } \\
\text { (malam) }\end{array}$ & $\begin{array}{l}\text { 1x shift setiap } \\
\text { hari }\end{array}$ \\
\hline & WT & 2 jam terputus-putus & $\begin{array}{c}3 \text { shift } 3 \\
\text { group }\end{array}$ & $\begin{array}{l}\text { 1x tiap shift } \\
\text { (malam) }\end{array}$ & 1x tiap shift \\
\hline
\end{tabular}

Tabel 2 Besaran nominal unsur biaya dan manfaat pada program PMT susu tahun 2017

\begin{tabular}{|c|c|c|c|c|}
\hline \multirow{2}{*}{ No } & \multirow{2}{*}{ Komponen } & \multicolumn{3}{|c|}{ Tahun 2017} \\
\hline & & Qty & Harga (Rp) & Jumlah (Rp) \\
\hline \multicolumn{5}{|c|}{ BIAYA } \\
\hline 1. & Anggaran & & 117.000 .000 & \\
\hline \multicolumn{5}{|c|}{ Biaya Langsung } \\
\hline 2. & Pembelian susu & 10.990 & 6.500 & 71.435 .000 \\
\hline 3. & $\begin{array}{l}\text { Pembelian bahan tambahan } \\
\text { (gula) }\end{array}$ & 144 & 12.500 & 1.800 .000 \\
\hline \multicolumn{5}{|c|}{ Biaya tidak Langsung } \\
\hline 4. & Biaya gaji pegawai & 3 & $\begin{array}{c}2.500 .000 \times 12= \\
30.000 .000\end{array}$ & 90.000 .000 \\
\hline 5. & Biaya listrik & 12 & 100.000 & 4.200 .000 \\
\hline 6. & Biaya gas & 120 & 25.000 & 3.000 .000 \\
\hline 7. & Biaya plastik & 192 & 8.000 & 1.536 .000 \\
\hline 8. & Biaya pembelian kulkas & 2 & 2.400 .000 & 4.800 .000 \\
\hline \multirow[t]{2}{*}{9.} & Biaya pembelian kompor gas & 4 & 350.000 & 1.400 .000 \\
\hline & TOTAL BIAYA & & 178.171 .000 & \\
\hline
\end{tabular}


(Net Present Value), IRR (Internal rate of return), dan BCR (Benefit Cost Rate). Sebelum menghitung NPV, IRR, dan BCR kita harus mengetahui Payback periode dari program yang ada. Menentukan lamanya investasi menggunakan metode periode pengembalian (payback periode).

\section{Payback Periode}

Metode ini menghitung berapa cepat investasi yang dilakukan dalam setiap periode. Biaya pengadaan program kesehatan PMT susu bernilai Rp. 178.171.000,- dan procced tiap tahunnya adalah hampir sama, yakni kurang lebih sebesar Rp. 117.000.000. Berdasarkan hasi perhitungan payback periode ini dapat disimpulkan bahwa program pemberian makanan tambahan susu akan memperoleh pengembalian dalam waktu 1 tahun 5 bulan.

$$
\mathrm{PP}=\frac{\mathrm{Rp} 178.171 .000}{R p \cdot 117.000 .000}=1,52=1 \text { tahun } 5 \text { bulan }
$$

\section{Metode nilai bersih sekarang (NPV: Net Present Value)}

Biaya pengadaan program PMT susu bernilai Rp. 178.171.000,- Umur ekonomisnya 1 tahun 5 bulan, kemudian akan dihitung besarnya nilai NPV dengan tingkat suku bunga diskonto yang diperhitungkan adalah $10,5 \%$.

$$
\begin{aligned}
& \text { NPV }_{1}=-178.171 .000+\frac{117.000 .000}{(1+0,105)^{1}}+\frac{117,000.000}{(1+0,105)^{2}} \\
& \text { NPV }_{1}=-178.171 .000+\frac{117,000,000}{1,105}+\frac{117.000 .000}{1,221} \\
& \text { NPV }_{1}=-178.171 .000+105.882 .352,94+95.823 .095,82 \\
& \text { NPV }_{1}=-178.171 .000+201.705 .448,76 \\
& \text { NPV }_{1} \quad=23.534 .448,76,-
\end{aligned}
$$

Berdasarkan hasil perhitungan diketahui bahwa nilai $\mathrm{NPV}_{1}$ untuk program pemberian makanan tambahan (PMT) susu adalah Rp. 23.534.448,76,- ini berarti bahwa nilai NPV 1 PMT susu tersebut $>0$, sehingga program pemberian makanan tambahan makanan tersebut dapat diterima. Yang artinya Investasi yang dilakukan memberikan manfaat bagi perusahaan.

Metode tingkat pengembalian internal (IRR: Internal Rate Of Return)

Metode tingkat pengembalian internal juga merupakan metode yang memperhatikan nilai waktu dari uang. Pada metode NPV tingkat bunga yang diinginkan telah ditetapkan sebelumnya, sedangkan pada metode IRR, kita akan menghitung tingkat bunga tersebut. Tingkat bunga yang akan dihitung ini merupakan tingkat bunga yang akan menjadikan jumlah nilai sekarang dari tiap-tiap procced yang di diskontokan dengan tingkat bunga tersebut sama besarnya dengan nilai sekarang dari nilai proyek/ program.

Pada program PMT susu IRR yang dihasilkan adalah $10,5 \%$ yang berarti program ini akan menghasilkan keuntungan dengan tingkat bunga 10,5\%. Dengan bunga 10,5\% yang perhitungannya diperoleh $\mathrm{NPV}_{1}$ positif Rp. 23.534.448,76,dari investasi awal Rp.178.171.000,- kemudian diperbesar nilai tingkat bunganya menjadi 8,5\% yang perhitungannya dapat diperoleh NPV nya positif Rp. 23.534.448,76,-- besarnya nilai $\mathrm{NPV}_{2}$ dengan tingkat suku bunga diskonto yang diperhitungkan adalah $8,5 \%$ maka besarnya NPV:

$$
\begin{aligned}
& \mathrm{NPV}_{2}=-178.171 .000+\frac{117.000 .000}{(1+0,085)^{1}}+\frac{117.000 .000}{(1+0,085)^{2}} \\
& N P V_{2}=-178.171 .000+\frac{117.000 .000}{1,085}+\frac{117,000.000}{1,177} \\
& N P V_{2}=-178.171 .000+107.834 .101,38+99.405 .267,62 \\
& N P V_{2}=-178.171 .000+207.239 .369 \\
& N P V_{2} \quad=29.068 .369
\end{aligned}
$$

Dari hasil perhitungan :

$\mathrm{I}_{1}=10,5 \%$

$\mathrm{NPV}_{1} \quad=23.534 .448,76,-$

$\mathrm{I}_{2}=8,5 \%$

$\mathrm{NPV}_{2}=29.068 .369$,-

$$
\begin{aligned}
& \text { Maka besarnya nilai IRR secara interpretasi adalah : } \\
& \text { IRR }=10,5+\frac{(10,5-8,5) x-23.534 .448,76}{23.534 .448,76-29,068.369} \\
& \text { IRR }=10,5+\frac{(47.068 .897,52)}{(-5.533 .920,24)} \\
& \text { IRR }=10,5+(-8,5) \\
& \text { IRR }=2
\end{aligned}
$$

Jadi besarnya IRR secara interpretasi adalah 2 berarti tingkat bunga pengembalian (Rate of Return) yang diinginkan lebih kecil dan investasinya tidak menguntungkan.

Metode perbandingan Manfaat dan Biaya (BCR : Benefit Cost Rate)

Metode BCR adalah suatu cara evaluasi suatu proyek dengan membandingkan nilai sekarang seluruh 
proyek/program diperoleh dari proyek/ program tersebut dengan nilai sekarang seluruh biaya proyek/ program tersebut. Berdasarkan metode ini, suatu proyek/ program akan dilaksanakan apabila $B C R>1$. Metode $B C R$ akan memberikan hasil yang konsisten dengan metode $N P V$, apabila $B C R \geq 1$ berarti pula $N P V>0$.

$$
\begin{aligned}
& B C R=\frac{\sum_{t=0}^{T} \frac{B t}{(1+i)^{t}}}{\sum_{t=0}^{T} \frac{B t}{(1+i)^{t}}} \\
& =\frac{\sum_{t=0}^{T} \frac{\text { Rp. } 446.446 .543 .309}{(1+0,105)^{13}}}{\sum_{t=0}^{T} \frac{\text { Rp. } 178.171 .000}{(1+0,105)^{13}}} \\
& \underline{\text { Rp.446.446.543.309 }}
\end{aligned}
$$

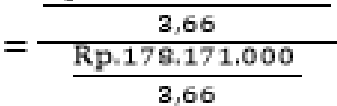

$$
\begin{aligned}
& =\frac{\mathrm{Rp} \cdot 121.979 .929,86}{\mathrm{Rp} \cdot 48.680 .601,09} \\
& =2,50
\end{aligned}
$$

Berdasarkan perhitungan BCR diperoleh hasil rasio $\geq 1$ yaitu rasio sebesar 2,5. Berdasarkan kriteria rasio benefit-cost maka dapat diambil kesimpulan investasi program pemberian makanan tambahan makanan (PMT) susu pada karyawan ini layak (feasible).

\section{Pembahasan}

\section{Keterbatasan}

Dalam penelitian ini peneliti memiliki keterbatasan yaitu:

1. Data-data sekunder yaitu data absensi karyawan dan kebijakan mengenai program PMT susu seperti laporan pembelian susu hanya diperoleh dalam waktu setahun, sedangkan program PMT susu telah berjalan selama 15 tahun hal ini dikarenakan tidak diperkenankannya atau keterbatasan akses memperoleh laporan-laporan tersebut.

2. Beberapa data seperti data pembiayaan BPJS, dan laporan produktivitas kerja diperoleh dari hasil seluruh kerja karyawan sedangkan dalam penelitian ini hanya meneliti karyawan penerima susu saja, sehingga memungkinkan adanya faktor lain yang menyebabkan tinggi nya total manfaat yang diperoleh dari pada total biaya yang dikeluarkan, dapat berupa dari peningkatan bahan baku, peralatan mesin yang digunakan karyawan, dan manajemen permasaran yang lebih baik dan lain-lain.

3. Asumsi besaran dari manfaat dan biaya yang dinilai dalam bentuk uang, berdasarkan wawancara, observasi, laporan keuangan dan data sekunder mengenai pengeluaran biaya, pengurangan angka kesakitan dan peningkatan nilai produksi pada tahun penelitian saja, sehingga dimungkinkan adanya perubahan nilai biaya dan manfaat pada tahun berikutnya.

Analisis biaya manfaat adalah proses identifikasi, pengukuran dan perbandingan sosial manfaat dan biaya proyek atau program investasi yang digunakan untuk mengevaluasi penggunaan sumber-sumber ekonomi agar sumber yang langka tersebut dapat digunakan secara efisien (Harry Campbel, 2003). Dalam menganalisis biaya dan manfaat dari suatu program kesehatan perlu diidentifikasi jenis biaya dan manfaatnya. Menurut Mangkoesoebroto (1998) dalam menentukan manfaat dan biaya suatu program atau proyek harus dilihat secara luas pada manfaat dan biaya sosial dan tidak hanya pada individu saja. Oleh karena menyangkut kepentingan masyarakat luas maka manfaat dan biaya dapat dikelompokkan dengan berbagai cara (Ferry, 2012).

Menurut Kenayathulla (2010), analisis biaya manfaat memiliki implikasi penting untuk mengembangkan kebijakan pendidikan yang realistis, berdasarkan fakta dan benar-benar adil dari manfaat jangka panjang bagi bangsa secara keseluruhan. Begitu juga dengan kebijakan kesehatan, dapat memliki implikasi yang penting dalam pengembangannya berdasarkan fakta, dan realistis untuk tujuan jangka panjang. Menurut Suryoputro, 2010, menyimpulkan bahwa analisis biaya dan manfaat untuk pelaksanaan program keselamatan dan kesehatan kerja cocok untuk pengembangan berkelanjutan perusahaan.

Berdasarkan penelitian Llewelyn \& Musianto (2000), yang meneliti tentang Cost Benefit Analysis pada Industri rokok, Indikator-indikator benefit dari industri rokok yang diperhitungkan adalah laba yang diterima oleh perusahaan rokok; cukai rokok yang diterima pemerintah dari perusahaan rokok; serta upah yang diterima karyawan dari perusahaan rokok. Sedangkan indikator-indikator cost dari 
industri rokok yang diperhitungkan adalah biaya yang dikeluarkan oleh masyarakat untuk membeli rokok; biaya perobatan yang harus dikeluarkan oleh masyarakat karena penyakit yang diderita akibat merokok; dan biaya kehilangan pekerjaan yang harus ditanggung oleh karyawan selama masa absen kerja, karena penyakit yang diderita akibat merokok.

Teknik metodologi dalam penelitian Cost Benefit Analysis dalam penelitian ini sama dengan penelitian sebelumnya, bahwa teknik studi penelitian CBA bersifat observasional deskriptif, dengan membandingkan biaya (cost) dengan manfaat (benefit), dengan langkah awal melakukan identifikasi biaya investasi dan biaya operasional. Dalam penelitian ini pun dilakukan identifikasi unsur biaya (cost) antara lain, biaya langsung yang terdiri dari biaya pembelian susu, biaya pembelian bahan tambahan (gula pasir), dan biaya tidak langsung terdiri dari biaya gaji pegawai, biaya pembayaran listrik, biaya pembelian plastik, biaya pembelian gas, biaya pembelian kompor gas dan biaya pembelian kulkas.

Pada penentuan nilai setiap unsur biaya (cost) dan unsur manfaat (benefit) dengan besaran nominal, diperoleh total biaya (cost) Rp.178.171.000,- dan total manfaat (benefit) Rp.446.446.543.309,- selisih antara total biaya (cost) dan manfaat (benefit) adalah sebesar Rp.446.268.372.309,- dimana total manfaat lebih besar dibandingkan dengan total biaya. Hal tersebut menunjukkan bahwa dengan selisih total antara total biaya (cost) dan total manfaat (benefit) dimana total manfaat lebih besar dari total biaya maka kemungkinan usulan tersebut dapat diterima sangat besar. Hal tersebut sesuai dengan teori yang menyebutkan bahwa semakin tinggi nilai total manfaat (benefit) maka makin tinggi nilai rasio BCR, sehingga makin tinggi pula nilai proyek/program yang bersangkutan.

Berdasarkan hasil penelitian yang telah dilakukan, hasil perhitungan payback period program PMT susu biaya investasi akan tertutup dalam waktu 1 tahun 5 bulan. Payback Period digunakan untuk menghitung berapa cepat investasi yang dilakukan dalam setiap periode, karena itu perhitungannya dinyatakan dalam satuan waktu (Doerachman, Kaunang, Karouw, \& Rindengan, 2010).

Pada perhitungan Net Present Value pada program PMT susu didapatkan hasil akhir NPV positif Rp. 23.534.448,76,- dengan discount rate 10,5\%. Maka dapat disimpulkan bahwa program PMT susu diterima karena NPV > 0 . NPV digunakan untuk menilai cost dan benefit secara keseluruhan dengan mengetahui perbandingan antara cost dan benefit, ,metode NPV dapat memberikan gambaran mengenai besarnya pengaruh keberadaan program PMT terhadap kesejahteraan karyawan (Llewelyn \& Musianto, 2000).

Berdasarkan hasil perhitungan rasio benefit-cost yang telah dilakukan hasil analisis program PMT susu didapat rasio 2,50 yang berarti berada pada posisi $\geq 1$ yang artinya program PMT susu tersebut dikatakan layak untuk tetap berlangsung. Metode BCR adalah suatu cara evaluasi suatu program dengan membandingkan nilai manfaat program diperoleh dari program tersebut dengan nilai sekarang seluruh biaya program tersebut (Ferry, 2012).

Berdasarkan metode ini, suatu proyek/ program akan dilaksanakan apabila $B C R>1$. Metode $B C R$ akan memberikan hasil yang konsisten dengan metode $N P V$, apabila $B C R \geq 1$ berarti pula $N P V>$ 0 . Hal ini terbukti dari hasil perhitungan yang telah dilakukan didapatkan hasil $\mathrm{BCR} \geq 1$ yaitu 2,50 dan NPV > 0, yaitu Rp. 23.534.448,76,-. Sehingga Program Pemberian Makanan Tambahan (PMT) susu di PT.Trisula Textile Industries Tbk Cimahi ini dikatakan Layak untuk tetap berlangsung. CBA merupakan suatu metode yang praktis untuk menentukan kelayakan dan daya tarik suatu proyek/ program dengan membandingkan manfaat yang diterima dan biaya yang dikeluarkan (Marini \& Rochmah, 2014).

Hasil analisa biaya dan manfaat tersebut di atas melambangkan rasionalitas ekonomi karena kriteria sebagian besar ditentukan dengan penggunaan efisiensi ekonomi secara global.. Program PMT di Pabrik Trisula ini menghasilkan manfaat yang lebih besar bagi kesehatan karyawannya daripada biaya yang dikeluarkan untuk program PMT tersebut, sehingga program PMT ini layak untuk dilanjutkan dan ditingkatkan kualitasnya. Kebijakan program PMT yang diterapkan di PT Trisula ini memberikan manfaat dalam meningkatkan kesehatan karyawan, terutama yang terpapar zat kimia. Penelitian ini memberikan hasil perhitungan dalam pengambilan keputusan untuk keberlangsungan suatu program kebijakan kesehatan.

\section{Kesimpulan}

Berdasarkan hasil penelitian yang telah dilakukan, maka dapat diambil kesimpulan : 
1. Hasil penentuan besaran nominal yang telah dilakukan program PMT susu didapatkan bahwa total manfaat (benefit) yang akan diterima yaitu penurunan angka kesakitan, peningkatan nilai produksi, dan produktivitas tenaga kerja adalah sebesar Rp.446.446.543.309,-- lebih besar dari total biaya (cost) yang di keluarkan perusahaan dalam progam PMT susu antara lain, biaya langsung yang terdiri dari biaya pembelian susu, biaya pembelian bahan tambahan (gula pasir), dan biaya tidak langsung terdiri dari biaya gaji pegawai, biaya pembayaran listrik, biaya pembelian plastik, biaya pembelian gas, biaya pembelian kompor gas dan biaya pembelian kulkas.Rp.178.171.000,- sehingga nilai total manfaat (benefit) lebih besar dari total biaya (cost).

2. Hasil total perhitungan payback period yang berfungsi untuk mengukur seberapa cepat modal (arus kas keluar/ investasi awal) dapat diterima kembali oleh perusahaan pada program PMT susu yaitu selama 1 tahun 5 bulan, maka biaya investasi program PMT tersebut akan tertutup dalam waktu 1 tahun 5 bulan.

3. Berdasarkan hasil perhitungan Net Present Value untuk mengetahui nilai uang sekarang pada program PMT susu didapatkan hasil akhir Rp. 23.534.448,76,-. Maka dapat disimpulkan bahwa program PMT susu diterima karena NPV $>0$.

4. Berdasarkan hasil perhitungan rasio benefitcost, didapat rasio 2,50 yang berarti berada pada posisi $\geq 1$ yang artinya program PMT susu tersebut dikatakan layak untuk tetap berlangsung.

\section{Daftar Pustaka}

Campbel, H \& Brown, R 2003. Benefit Cost Analysis. Newyork: Cambridge University Perss.

Doerachman, J. D., Kaunang, Karouw, S. D. S., \& Rindengan, Y. D. Y. 2010. Analisa Kelayakan Investasi TI Menggunakan Metode Cost-Benefit. Jurnal Teknik Informatika Universitas Sam Ratulangi. 1 (2)

E.J.Lean, M. 2013. Ilmu Pangan Gizi dan Kesehatan. Jakarta: Pustaka Pelajar.

Ferry, P. 2012. Modul Ekonomi Publik Bagian Vi: Analisis Biaya Dan Manfaat, 1-37. Available from <http://ferryfebub.lecture.ub.ac.id/files/2013/01/
Bagian-VI-Analisis-Biaya-dan-Mnafaat.pdf> Heniwati \& Thabrany, H. 2016. Perbandingān Klaim Penyakit Katastropik Peserta Jaminan Kesehatan Nasional di Provinsi DKI Jakarta dan Nusa Tenggara Timur Tahun 2014. Jurnal Ekonomi Kesehatan Indonesia. 1(2).

Kenayathulla, Husnaina B. 2010. Cost Benefit Analysis in Malaysian Education. Jurnal Internasional Manajemen Pendidikan.. 4 (2).

Kemenkes. 2017. Petunjuk Teknis Pemberian Makanan Tambahan (PMT) 2017. Kementerian Kesehatan Republik Indonesia. Jakarta

Kemenperin. 2016. Jumlah Pekerja Industri Ditargetkan 16,3 Juta Tahun 2017. Kementerian Perindustrian Republik Indonesia.

Khomsan, A. 2010. Pangan dan Gizi untuk Kesehatan. Jakarta: PT Raja Grafindo Persada.

Llewelyn, R., \& Musianto, L. .2000. Analisis CostBenefit Terhadap Industri Rokok di Indonesia. Jurnal Manajemen \& Kewirausahaan. 2 (2): 68 - 85.

Mangkoesoebroto, G.1998. Teori Ekonomi Makro. Yogyakarta: FE UGM.

Marini, E., \& Rochmah, T. N. 2014. Cost Benefit Analysis mendirikan Laboratorium Klinik Sederhana Mandiri dibanding Kerjasama Operasional Laboratorium Luar Di Plk- Ua Cost. Jurnal Administrasi Kesehatan Indonesia. 2 (2)

Misuraca, Pamela. 2014. The Effectiveness of a Costs and Benefits Analysis in Making Federal Government Decisions: A Literature Review. Center for National Security, The MITRE Corporation Muslim, I \& Partiwi, S.G. 2015. Development Of CostBenefit Calculation Model In Handling Low Back Pain From The Ergonomic Perspective. Proceeding 8th International Seminar on Industrial Engineering and Management. ISSN: 1978-774X

Nazir, Moh. 2005. Metode Penelitian. Bogor: Ghalia Indonesia.

Raushan, Jahongir, Ziyodullo. 2014. A Cost-Benefit Analysis of Early Childhood Hygiene Interventions in Uzbekistan. Eurasian Journal of Business and Economics 2014, 7 (14): 183-208

Sitorus E \& Nurwahyuni, A. 2017 Analisis Pembiayaan Kesehatan Bersumber Pemerintah di Kota Serang Tahun 2014-2016. Jurnal Kebijakan Kesehatan Indonesia. 6 (3).

Suryoputro, M. R \& Rahadian, H. 2010. Cost and Benefit Analysis for Implementation of Occupational Safety and Health. The 11th Asia 
Pacific Industrial Engineering and Management Systems Conference The 14th Asia Pacific Regional Meeting of International Foundation for Production Research. Melaka 2010.

Undang-Undang Republik Indonesia Nomor 13

Tahun 2003 Tentang Ketenagakerjaan. 